\title{
ON PROF. DANIEL GEORG BALK (1764-1826), SUPERVISOR OF KARL ERNST VON BAER'S DOCTORAL THESIS ON ESTONIANS' ENDEMIC DISEASES
}

\author{
(for K. E. von Baer's $220^{\text {th }}$ birth anniversary) \\ JAAN KASMEL, TIIU KASMEL \\ Centre for Physical Anthropology, University of Tartu, Estonia
}

Karl Ernst von Baer (1792-1876), a graduate of the University of Tartu, which will celebrate its $380^{\text {th }}$ anniversary in October this year, can be considered one of the most renowned natural scientists of the $19^{\text {th }}$ century. His $220^{\text {th }}$ birth anniversary was at the end of February this year.

His work and activities have influenced the development of embryology, zoology, geography, geocryology, ichthyology, geomorphology, archaeology, ornithology, botany and climatology.

K. E. von Baer may also be called an ethnographer, anthropologist, medical scientist, historian, bibliographer, philosopher, populariser of science, reformer of education and science in Russia, researcher of local history and manor economy manager (1834-1866 he was the owner of Piibe and Selli manors) [1].

A few years ago, Aadu Must, Professor of Archival Studies at the University of Tartu, public figure and politician, relying on sources found in Russian archives, discovered the surprising fact that K. E. von Baer was also one of the founders of the Russian analytical intelligence service and its main ideologist [2].

Archive dossiers may still hide many unknown materials and facts about K. E. von Baer. 
The first step in his long and fertile career as a scientist was the doctoral dissertation On Estonians' Endemic Diseases, which was defended it in front of the Council of the Faculty of Medicine of the Imperial University of Dorpat (the present University of Tartu) on 29 August 1814.

The documents on the defence of his doctoral thesis and the preceding exams are preserved in the Estonian Historical Archives as a separate storage item. Along with documents in German and Latin on 17 pages, the file also includes the doctoral diploma given to Baer, his doctoral thesis in Latin (88 pp.) and the diploma given to Baer by the Medical Faculty of the University on the $50^{\text {th }}$ anniversary of the defence of his doctoral thesis [3].

Forty years ago, at a conference to mark Baer's $180^{\text {th }}$ birth anniversary, Associate Professor of Tartu State University (now the University of Tartu) Tullio Ilomets made a presentation On the defence of Karl Ernst von Baer's doctoral dissertation. An extended version of the presentation was published in the collection Folia Baeriana I (Tallinn: Valgus 1975, 184 pp., 1000 copies), which shows that, in addition to the above-mentioned archive file, the author has used 13 other publications.

With this collection, the publication of Baer's original papers in Estonian began. The first to be published in Estonian was the translation of his Latin thesis, on pages 141-181 of the collection [4].

In the following year, 1976, the Estonian translation of Baer's dissertation appeared in Issue 33 of Loomingu Raamatukogu series in 25,000 copies [5].

The doctoral dissertation and the Latin materials of the archive file were translated into Estonian by Ülo Torpats, a lecturer of Tartu State University [3].

Thus, it has been possible for everyone who knows Estonian to read Baer's doctoral thesis for more than 35 years. Estonians have found quite interesting facts in it, as it deals with the life and health of Estonian serf peasants in the early $19^{\text {th }}$ century, being a valuable source on the history of sanitation and hygiene in Estonia.

The printed version of Baer's doctoral dissertation in Latin, like its reprint in 1938, have become bibliographical rarities.

Relatively little has been written about the content of his doctoral thesis as a medical-geographical study. The papers describing it have been limited to summaries of the chapters and do not contain any analyses of problems. The main reasons seem to be the local character of the theme, treatment of a geographically limited area and the fact that the thesis was written in Latin [3]. 
Baer's choice of the theme for his doctoral thesis On Estonians' Endemic Diseases was influenced by Daniel Georg Balk (1764-1826), Ordinary Professor of Pathology, Semiotics, Therapy and Clinic [6].

In his autobiography Baer notes that he felt well prepared for the theme, as in his boyhood he had accompanied his private teacher when the latter visited peasant families to treat illnesses. Command of the Estonian language enabled him to communicate directly with the country people; when collecting specimens for his herbarium in Estonia and Livonia, he had learned to recognise many medicinal plants.

In his thesis Baer relies on observations made at the clinics of the University of Tartu, Riga military hospital and on expeditions, also on literary sources that describe Estonians' way of life and health status [7].

The thesis consists of a preface and five chapters. The second chapter of Baer's doctoral thesis (On Estonians' customs) is of particular interest from the anthropological point of view, as it provides an overview of the Estonian people in general, their dwellings, clothing, food and drink. It also describes Estonians' physical development and temperament, taking care of one's body and lifestyle during different seasons [4].

The short description of Estonians' habitus (body build) compiled by him is a telling example of the anthropological thinking of the period.

Baer's doctoral thesis can be considered the first paper that thoroughly dealt with Estonians' anthropology. It marks the beginning of Estonians' anthropological research [8].

Because of the description of Estonians' body build and appearance, the thesis can also be considered an anthropological-medical-geographical paper.

Prof. D. G. Balk, the scientific supervisor of K. E. Baer's doctoral thesis, has found little or no attention in publications about K. E. von Baer's doctoral thesis, its writing and defence.

Therefore, we are going to discuss Prof. Balk's activities as Ordinary Professor of Pathology, Semiotics, Therapy and Clinic and a developer of anthropology at the Imperial University of Dorpat from 1802-1817.

In addition, we are trying to establish by whom, when and under what conditions the teaching of anthropology - the academic study of humans began at the Medical Faculty of the University of Tartu, and what the University Statutes that were in effect then said about the teaching of that subject.

During its 380 years of existence, the University of Tartu has gone through a complex and discontinuous route of development. The university has 
sometimes even changed its location, but throughout its history it has included the Faculty of Medicine. Among the numerous disciplines taught at the faculty, one of the oldest and most essential ones is anatomy. Its teaching began as soon as the enlightened Swedish king Gustavus II Adolphus gave permission to open a university with four faculties in Dorpat (Tartu) in war-ravaged Livonia from 15 (25) October 1632 [9].

Although the roots of anthropology (the Greek for 'the study of humans') go back to the distant past, and even the term dates from Aristotle (384-322 $\mathrm{BC})$, it became established as a separate branch of science as late as in the $19^{\text {th }}$ century. This had been facilitated by expeditions of discovery and the development of natural sciences, particularly of anatomy [10]. It is not always easy to tell when anthropology began to be taught at one or another university as detailed research into the matter is lacking.

To get a comprehensive answer to our last question, we should look back at the history of the Faculty of Medicine at the University of Tartu, starting from the first two periods of the university under the Swedish rule when tuition was in Latin. By the statutes of Academia Gustaviana Dorpatensis (1632-1665) and Academia Gustavo-Carolina (1690-1710), which were modelled on the statutes of Uppsala University, the Faculty of Medicine was to have two professors. One of them was supposed to lecture on anatomy, botany and physics, and the other had to teach illnesses and their treatment. Annually a dissection was to be arranged. However, due to the small number of students, often only one professor's post was filled, and sometimes even that was vacant. All the professors of medicine who worked in Dorpat (Tartu) were at the level of their time as they had studied at the best universities of Europe [11].

As elsewhere, professors began to pay increasing attention to the issues of human body and spirit, which corresponded to the dualist treatment typical of that time's anthropology.

Despite many difficulties, during both periods teaching and research at the university was more or less met the academic standards of the time. Unfortunately, the activity of the only Livonian university was interrupted by the epidemic of plague that broke out in the summer of 1710 during the Northern War. Opportunities to continue it came as late as at the end of the century [9].

Hoping to prevent the inflow of the ideas of the French Revolution to Russia, Paul I in his ukase of 9 April 1798 forbade Russian subjects to study at Western European universities. They were ordered to return home in a few following months. Simultaneously with the ban, the Baltic knighthoods were 
allowed to quickly open a local Protestant university for the whole Russian Empire, and particularly for the knighthoods of Estonia, Livonia and Courland. Its location was to be chosen by an agreement between the knighthoods. From the beginning, it was supposed to bear the name of "imperial university", although its had to be financed by the knighthoods. The representatives of the latter prepared a plan for founding the university but failed to reach an agreement about its location. Finally the Senate was offered two towns to choose from: Mitau (Jelgava) and Dorpat (Tartu). The Senate favoured the latter as the seat of the university because of its central location in the Baltic provinces, favourable climate and cheapness of foodstuffs, which was supposed to offer better opportunities for less well-off parents to send their children to the university [12].

On 4 May 1799 Paul I confirmed the resolution of the Senate and the plan for instituting the university, which in its essence became the provisional statutes of the University. The plan provided for a total of 22 professors in the faculties of theology, law, medicine and philosophy, and teachers of several subjects, mostly of languages. Thus it covered nearly all the principal research areas of that time. The system of teaching was to follow the model of Western European universities and the Russian university in Moscow. The Faculty of Medicine was to have six full professors. The subjects taught at the Faculty of Medicine were divided between them as follows: 1) physiology and pathology; 2) therapy and clinic; 3) anatomy and medicina forensis (forensic medicine); 4) surgery and obstetrics; 5) botany and materia medica (pharmacology); 6) chemistry and pharmacy.

The same plan envisaged the foundation of several ancillary institutions at the faculties. The university as a whole was to have a library, a manege, a dance hall and a bathing establishment. The plan also included the annual budget of the university, which covered the expenses for the staff and ancillary institutions [13].

Preparations followed for finding lecturers and putting the university into operation, as the opening of the university had been planned for 15 January 1801.

The first members of the Faculty of Medicine who were appointed to their posts on 14 December 1800 were full professor of anatomy and forensic medicine Martin Ernst Styx and full professor of chemistry and pharmacy Philipp Erdmann Heinrich Gottlob Arzt [14].

While the preparations for opening not only the Medical Faculty but the whole university were in progress, Paul I unexpectedly changed his mind and 
on 25 December 1800 still appointed Mitau (Jelgava) as the location of the university instead of Dorpat (Tartu) as the knighthoods of Courland and Pilten had submitted a respective application. However, the emperor's sudden death on 12 March 1801 prevented the execution of this order. The new emperor Alexander I, on 12 April 1801, appointed Dorpat (Tartu) again as the seat of the university, substantiating it with its central location, congenial surroundings and several other reasons, including the fact that there had been a university in Dorpat (Tartu) before. The situation had changed in favour of Dorpat (Tartu) again, this time conclusively. Now it would be more appropriate to speak about the re-opening the university in Dorpat (Tartu), not its opening, as years ago, in the early $18^{\text {th }}$ century it had wound up its activities there. (It would be even more exact to speak about its second reopening as for the first time the university had been re-opened in 1690).

In such a complicated situation the curators of the university found it necessary to introduce several changes and additions to the plan of opening the university in order to strengthen their influence over the university council that consisted of professors [12].

The university statutes confirmed by the ukase of Alexander I of 5 January 1802 provided only 19 professors for all the four faculties. While the foundation plan of the university envisaged six full professors for the Medical Faculty, then the statutes confirmed two years and eight months later had reduced the number of positions to four. As hygienic disciplines had been added, the number of disciplines to be taught by the faculty had increased. The subjects were divided between the professors as follows: 1) anatomy, physiology, surgery and obstetrics; 2) pathology, semiotics, therapy and clinic; 3) dietetics, public and popular medicine and materia medica; 4) chemistry and pharmacy. The professor of public medicine also had to lecture on the main hygienic disciplines and forensic medicine.

The statutes did not introduce any changes into the number ancillary institutions affiliated to the Faculty of Medicine and supervision of their work [15].

In addition to the two professors who had already been appointed, the third was employed on 27 February 1802, before the re-opening of the university according to the new statutes - Daniel Georg Balk, full professor of pathology, semiotics, therapy and clinic [14].

The preparations for re-opening the university were brought to a conclusion in April 1802 when, in addition to the first professors, the first students were enrolled from 5 April. On 21-22 April 1802 the University of 
Dorpat (now Tartu) was festively re-opened after a long interval of 91 years and 8 months.

On 1 May work began in the four faculties of the only German-language university of the Russian Empire with 9 professors and 19 students. The Faculty of Medicine started with three full professors instead of four; all of them were engaged in teaching during the first semester, which lasted for two months. The post of the professor of anatomy, physiology, surgery and obstetrics remained vacant. The number of students at the faculty was a modest six.

In the first years after the re-opening the university suffered not only from a shortage of lecturers who would have met the requirements but also from lack of suitable rooms. Classes were held in private houses and flats rented for that purpose. Therefore, the construction of new, up-to-date buildings became topical, as the number of students was growing fast.

At the time there were no stable obligatory curricula at the university. The duration of studies had not been fixed, although at the Medical Faculty it was initially two years. Checking of knowledge acquired by the students was superficial and unsystematic. Along with obligatory lectures professors gave students individual tuition and rarely supervised some practical work. Thus, a number of problems concerning the organisation of studies had to be solved $[12]$.

To improve the university structure and management, new statutes were approved on 15 September 1803. These provided four full and two extraordinary professors for the Medical Faculty. The disciplines were divided between the full professors as follows: 1) anatomy, physiology and forensic medicine; 2) pathology, semiotics, therapy and clinic; 3) dietetics, materia medica, history of medicine and medical literature; 4) surgery and obstetrics. In addition to these, there was to be a post for a professor extraordinary in veterinary medicine. Under the statutes of 1803 the prosector of the anatomical theatre also got for the first time the rights and obligations of a professor extraordinary [16].

The university staff as envisaged in these statutes was quite numerous for its time - a total of 29 professors and 12 lecturers. Compared to the 1804 statutes of Moscow University, which provided for 28 professorships, the University of Tartu could be very satisfied; theology even got more professorships here (four) than in Moscow (two) [12]. The new statutes introduced several changes concerning the ancillary institutions of the Faculty of Medicine. As the teaching of chemistry was transferred to the Faculty of Philosophy, the 
chemistry laboratory was also included among the ancillary institutions of that faculty. The list of ancillary institutions of the Medical Faculty, however, had been supplemented with the collection of anatomical specimens and the pathology study room. The former was to be supervised by the professor of anatomy and the latter by the professor of pathology. The collection of anatomic specimens was to be located at the anatomical theatre; the location of the pathology study room was not specified. The clinical institute that was envisaged for the Medical Faculty in the plan of foundation of the university, was renamed by the 1803 statutes the medical clinical institute and the surgical hospital the surgical clinical institute. No changes were made in the administration of the renamed ancillary institutions and the maternity hospital [16].

The question we were interested in - what the university statutes said about teaching of anthropology at the Faculty of Medicine - could be answered, after a cursory examination: neither the statute of the Swedish university nor the foundation plan of the university (approved in 1799) and the first statutes $(1802,1803)$ provided for teaching of anthropology at this faculty.

However, looking through the lecture programmes of the university revealed that in the autumn semester of 1802 (from 1 August to the end of December) the list of lectures by the full professor of pathology, semiotics, therapy and clinic D. G. Balk started with lectures of medico-philosophical anthropology for the students of the Medical Faculty, four hours a week, one hour each time [17].

His lectures were based on the textbook Medizinisch-Philosophische Anthropologie für Aerzte und Nichtaerzte (Medico-philosophical anthropology for doctors and non-doctors) by Johann Daniel Metzger (1739-1805), physician in ordinary to the Prussian king, privy councillor, and professor of Königsberg University. This publication served as the recommended textbook for giving academic lectures. The book consisted of an introduction and six chapters. For its time, the first chapter gave a thorough overview of the descent of man. The following chapters dealt with medical psychology, physiology, dietetics, pathology and therapy [18].

Prof. Balk's lectures on medico-philosophical anthropology were followed by lectures on general pathology. In addition, he lectured on the influence of galvanic electricity on living and dead animals by applying an experimental method. He may have been the first lecturer in the Russian Empire to illustrate his lectures with experiments. 
As the professor of anatomy had not arrived as yet, he also taught osteology, which was accompanied by a demonstration of bone specimens.

During the autumn semesters of the next two years Professor D. G. Balk taught physico-philosophical anthropology as a preparatory course for purely philosophical anthropology. Then, during the autumn semester of 1805 , he taught natural historico-philosophical anthropology as a prerequisite for purely philosophical anthropology.

During the spring semesters of 1807 and 1808 Prof. Balk taught physiologico-philosophical anthropology as an introduction to philosophical anthropology.

In total, he lectured on anthropology during four autumn and two spring semesters. In his lectures he presented an assemblage of knowledge on the human being that fully met the requirements for teaching anthropology at that time.

All the above-mentioned courses were taught within the same number of hours and according to the textbook by J. D. Metzger.

As visual aids for the lectures, Prof. Balk used specimens from his anatomico-pathological collection (which he himself called a museum). Thus he laid the foundation to the specimens collection of both normal and pathological anatomy at the University of Dorpat (Tartu) and, indirectly, also to the anthropological collection. Because Prof. Balk had started the anatomico-pathological collection, the university statutes of 1803 included the collection of anatomical specimens and the pathology study room in the list of the ancillary institutions of the Medical Faculty.

The list of Prof. D. G. Balk's lectures is not short. He taught introduction to pathology, general ja special pathology, semiotics, health science and, to law students, medico-philosophical jurisprudence according to his own study aid. He is known to have claimed as early as in 1795 that each judge should have knowledge of forensic medicine, medical police and anthropology, and should pass examinations in these subjects before taking office. Moreover, he used to teach general therapy, casuistic medicine, gynecological diseases, special pathology and therapy of children's and fever diseases, general medical science, suspended animation, diseases that may result in sudden death, the art of writing prescriptions, venereal diseases, forensic medicine, treatment of chronic skin diseases, pathology and treatment of mental diseases, introduction to surgery, surgery, medical encyclopaedia and methodology. During a number of semesters he also supervised clinical practice [19]. 
Next we present an overview of Prof. D. G. Balk's life and work before taking office at the university and during his service here, as in the autumn semester of 1802 he was the first to start teaching anthropology to the students of the Medical Faculty of the University of Tartu (Dorpat).

Daniel Georg Balk was born in Königsberg in the family of an amber polisher on 23 June 1764 . He got his first education at home and at school from 1775 [14]. From 1780-1787 he studied at the Medical Faculties of Königsberg and Berlin Universities [20]. In 1787 he earned his doctorate of medicine at Königsberg University. His dissertation studied irritants of skin and the mucous membrane.

Thereafter he practised medicine in Courland and Lithuania. In 1796 he was appointed district physician of Jakobstadt (Jekabpils). On 28 June 1799 Balk became the doctor of Baldone health resort, which is located $33 \mathrm{~km}$ from Riga. The numerous medical books he wrote during this period point to the drawbacks in health service and emphasise the need to protect one's health and the social significance of health. In his opinion, training of physicians at local universities would give better results than studying abroad.

Balk's proposals concerning the health service had a reformative character and were progressive for his time. In addition, Balk revealed a literary genius and took a deep interest in the theatre. His fame grew after he took measures against the cattle plague that ravaged the entire Courland at the turn of the century. This was the reason why he was invited to become the first professor of pathology, semiotics, therapy, and clinic at the University of Dorpat (Tartu) in 1802 .

As a professor, D. G. Balk became actively involved in the development of the university. In a number of his speeches he drew attention to the human being, educational problems, and the physical and intellectual development of the human being.

As the second Rector of the University of Dorpat (Tartu) (from 1 August 1803 to 1 August 1804) and four-time Dean of the Faculty of Medicine (18041805, 1808-1809, 1811-1812, 1815-1816), Prof. Balk made an important contribution to the development of the university and the Medical Faculty [21]. He was involved in the construction of the so-called Old Anatomical Theatre, which began on 8 June 1803. In addition, he was involved in the construction of the clinics in 1806-1808 [22].

In the first half of 1804 Professor D. G. Balk introduced clinical practicums to the curriculum. On 1 May of the same year he opened the first polyclinic in the Russian Empire, which applied rudiments of serving the population 
according to the territorial principle. In 1808 he set up an emergency medical aid station, which can be considered the first in Russia.

He also set up a hydropathic establishment that was affiliated to the clinic and a school for teaching of female nurses. Prof. Balk contributed a lot to the treatment of sick and wounded soldiers in the wars of 1807 and 1812-1813 $[21]$.

Prof. D. G. Balk also participated actively in the administration of research.

Professor of anatomy, physiology and forensic medicine Karl Friedrich Burdach has stated that most dissertations written at the Medical Faculty of the University of Dorpat (Tartu) during its first 15 years reflected Balk's views [1].

To stimulate students' interest in independent research, the university statutes of 1803 provided that prize essays should be written. Prof. D. G. Balk also participated in supervising students' research activities. The first prizes for essays were awarded in 1805. The essay by stud. med. Otto Girgenson On the Relations between Medicine and Philosophy, which received the gold medal, was supervised by Prof. Balk [12].

Unfortunately, we do not have any photographs of Prof. D. G. Balk. Johann Wilhelm Krause (1757-1828), professor of agriculture, technology and architecture, described him as a man of noble appearance with fine features and slender build. He is said to have been characterised by wisdom, wit, sense of humour, and skill at work [23].

For his diligent work Professor Balk was awarded three valuable diamonds rings.

Because of his uncompromising character he had a number of arguments with Prof. Georg Friedrich Parrot (1767-1852), Rector of the university for several terms, and some professors of the Medical Faculty. In his later years at the university he began to spend more time in the Musse, drinking and gambling there. All this, including his participation in theatrical performances, served as a reason for accusing Prof. Balk of immorality. On 5 June 1817, at the age of 53, Balk was forced to leave the university, whereby he lost the privileges for himself and his children, which were provided for in the foundation plan of the university. Balk left for Tula where he died early in 1826 [21].

The lectures on medico-philosophical anthropology by full professor of pathology, semiotics, therapy and clinical medicine D. G. Balk in the autumn semester of 1802 and this course of lectures as a whole were the first at the University of Dorpat (Tartu) in the field of anthropology. 
Anthropology can be regarded as one of the first academic subjects introduced by Prof. D. G. Balk at the Faculty of Medicine of the University of Tartu 210 years ago.

In addition to Prof. Balk's lectures on anthropology that started in 1802, Prof. H. Fr. Isenflamm started to lecture on anthropology in the autumn semester of 1803, and in the spring of 1805 Professors M. E. Styx and L. E. Cichorius followed.

After that the number of faculty members who taught anthropology declined constantly, and, eventually, after 13 years these lectures were discontinued [19].

Here it would be proper to ask when teaching of anthropology started in the other older universities of Czarist Russia. At Moscow University (the oldest university of Czarist Russia), Ivan Fyodorovich Vensovich (1769-1811), Professor of Anatomy, Physiology and Forensic Medicine, reported for the first time about the need to teach anthropology at Moscow University in 1805 in his festive speech at the celebrations of the $50^{\text {th }}$ anniversary of the university [24]. By then anthropology had been taught in Dorpat (Tartu) for three years already. The year 1805 could still be considered as the peak of teaching anthropology at the University of Dorpat (Tartu) throughout its history. At that time four professors at the Faculty of Medicine were dealing with it - D. G. Balk, H. F. Isenflamm, M. E. Styx and L. E. Cichorius. It is known that they were teaching five different courses on anthropology or courses that included elements of anthropology. The other older universities of Czarist Russia were established or restored after the reopening of the University of Dorpat (Tartu) in 1802 [12]. Therefore, Prof. D. G. Balk's lectures on medico-philosophical anthropology delivered during the autumn semester of 1802, and this lecture course as a whole, can be regarded as the first of its kind at any university of the Russian Empire.

Several authors have written that Prof. D. G. Balk has made an important contribution to popularisation of hygiene in the Baltics, the development of clinical medicine in Tartu, and the development of polyclinical medicine in Russia [21].

He can be regarded as an outstanding physician in the Baltics at the end of the $18^{\text {th }}$ and the beginning of the $19^{\text {th }}$ century who was also influential in the development of anthropology at the University of Dorpat (Tartu) and in Tsarist Russia. 


\section{REFERENCES}

1. Kaavere V. (1992). Baer. Tartu.

2. Ajaloolane: Karl Ernst von Baer oli Venemaa luure asutaja (2010). Postimees, 10.01 .

3. Ilomets T. (1975). Karl Ernst v. Baeri doktoritöö kaitsmisest. In: Folia Baeriana I. Tallinn: Valgus, 113-115.

4. Baer K. E. (1814). Eestlaste endeemilistest haigustest. In: Folia Baeriana I. Tallinn: Valgus, 141-181.

5. Baer K. E. (1814). Eestlaste endeemilistest haigustest. In: "Loomingu" Raamatukogu, 33. Tallinn: Perioodika, 7-56.

6. Kalnin V. (1967). C. E. Baeri doktoriväitekirjast. Nõukogude Eesti Tervishoid, 3: 228-229.

7. Kalnin V. (1976). Ääremärkusi ja selgitusi K. E. v. Baeri doktoriväitekirja juurde. In: "Loomingu" Raamatukogu, 33. Tallinn: Perioodika, 59-62.

8. Ауль Ю. (1964). Антропология эстонцев. Тарту.

9. Tartu Ülikooli ajalugu I. 1632-1798. Koost. H. Piirimäe. Tallinn: Valgus, 1982.

10. Тегако А. И., Саливон И. И. (1989) Основы современной антропологии. Минск.

11. Mikelsaar R.-H. (1998). 300 aastat sektsioonikursust ja patoanatoomiat Tartu Ülikoolis. Eesti Arst, 6: 544-548.

12. Tartu Ülikooli ajalugu II. 1798-1918. Koost. K. Siilivask. Tallinn: Eesti Raamat, 1982.

13. Plan der errichtenden Universität. [Riga, 1799].

14. Аевицкий Г. В. $(1902,1903)$. Биографический словарь профессоров и препоАавателей Императорского Юрьевского университета за сто мет его существования. Т. І, Юрьев; Т. ІІ, Юрьев.

15. Statuten der Kayserlichen Universität zu Dorpat. Dorpat, 1802.

16. Statuten der Kaiserlichen Universität zu Dorpat. Dorpat, [1803].

17. Verzeichnis der Vorlesungen auf der Kaiserlichen Universität in Dorpat vom 1. August bis Ende Dezember des Jahres 1802. Dorpat, 1802.

18. Metzger J. D. (1790). Medizinisch-Philosophische Anthropologie für Aerzte und Nichtaerzte. Leipzig.

19. Verzeichnis der haltenden Vorlesungen auf die Kaiserlichen Universität zu Dorpat, 1803-1817. Dorpat, 1803-1817.

20. Album rectorum Universitatis Tartuensis 1632-1997. Tartu, 1997.

21. Kalnin V. (1996). Daniel Georg Balk. In: Eesti arstiteaduse ajaloost. Ed. V. Kalnin. Tartu: 25-29.

22. Normann H. (1925). Katkend Tartu Ülikooli arstiteaduskonna algetest. Eesti Arst, 11: 323-332.

23. Krause J. W. Kunagise Tartu ülikooli esimene aastakümme. In: Mälestusi Tartu ülikoolist (17.-19. sajand). Ed. S. Issakov. Tallinn, 1986. 
24. Залкина Н. Г. (1974). Московская школа антропологов в развитии отечественной науки о человеке. Москва.

\section{Address for correspondence:}

Jaan Kasmel

Centre for Physical Anthropology

University of Tartu

Lossi 38, Tartu 51003

E-mail: jaanjkasmel@hot.ee 